\title{
Body Mass Index, Participation, Duration of Work and Earnings under NREGS: Evidence from Rajasthan
}

\author{
Raghbendra Jha, Raghav Gaiha \& Manoj K. Pandey ${ }^{1}$
}

\begin{abstract}
Despite its evident importance relatively little is known about links between Body Mass Index (BMI) and participation in workfare programs, particularly in India. Using a unique data set for the Indian state of Rajasthan for 2009-10, this paper attempts to fill this void and examines the association between BMI and participation in, duration of employment in and earnings from employment in NREGs. Thus we go beyond the scope of the extant literature and model these links for both male and female workers with varied social and economic backgrounds. Further, we permit non-linearities in some impacts and allow for mutual endogenity, say, between BMI and earnings. To the best of our knowledge this is the first paper to examine this range of issues.
\end{abstract}

Keywords: Body Mass Index, National Rural Employment Guarantee, Participation, India

JEL Classification: C21, D31, D63, H53

All correspondence to:

Prof. Raghbendra Jha, Australia South Asia Research Centre, College of Asia and the Pacific

H.C. Coombs Building (09)

Australian National University, Canberra, ACT 0200, Australia

Phone: + 6126125 2683; Fax: + 6126125 0443; Email: r.jha@anu.edu.au

\footnotetext{
${ }^{1}$ Jha: Australia South Asia Research Centre, College of Asia \& the Pacific, Australian National University, Canberra, Australia (email: r.jha@anu.edu.au). Gaiha: Faculty of Management Studies, University of Delhi, Delhi, India. Pandey: Australia South Asia Research Centre, College of Asia \& the Pacific, Australian National University, Canberra, Australia (email: manojkp23@gmail.com). We gratefully acknowledge financial support from Australian Research Council-AusAID Linkage grant LP0775444 and Raj Bhatia for expert statistical advice. The usual caveat applies.
} 



\section{Introduction and Motivation}

It has long been recognized that a worker's health and nutritional status are, ceteris paribus, fundamental determinants of the worker's labor market performance. This includes extent of participation in labor markets and wages earned.

Much empirical work, surveyed in particular by Han et al. (2009), has suggested that there exists a negative relation between Body Mass Index (BMI) and wages in most cases. Han et al. (2009) themselves consider a more nuanced approach by allowing the marginal effect of non-linear BMI groups to vary by gender, and other characteristics of workers. Their results indicate that the negative link between BMI and wages is greater in occupations requiring interpersonal skills and social interaction. This wage penalty increases for workers beyond their mid twenties.

On the other hand, Greve (2007) estimates the relation between BMI and wages and discovers that this link depends on the sector of employment. Thus, in the private sector body weight has a negative effect on wages for women but a positive effect for men, whereas in the public sector body weight has no influence on wages for either men or women.

Along the same lines Cawley (2000) studies the link between BMI and wages at a more disaggregate level. Three labor market outcomes are studied: hourly wages, employment, and sector of occupation. This paper finds that excessive weight lowers wages for white women. But there is only weak evidence that weight lowers wages for Hispanic women, and no evidence that weight lowers the wages of black women. There is no effect of weight on the probability of employment or sector of occupation.

Thomas and Strauss (1997) study the impact of height of workers on their wages in urban Brazil. They discover that BMI is associated with higher wages; ceteris paribus taller men and women earn more. BMI is associated with higher wages- particularly among men, especially among the less educated- suggesting that strength may be rewarded.

In another important contribution, Deolalikar (1988) demonstrates that weight-for-height affects wages and productivity in rural South India.

For a review of the evidence in developing countries and policy options, see Preker et al. (2007). 
In a stylised model of India’s rural labour market, Baland et al. (1996) propose an interesting model of why piece rate favour higher participation of those with greater physical stamina and dexterity. This is particularly relevant in the context of the National Rural Employment Guarantee Scheme in India which uses a piece-rate system.

In addition there is a parallel literature on the impact of weight at birth on later economic outcomes for the child. However, Black et al. (2007) argue that the adverse economic impact of low birth weight on economic outcomes later in life arises largely because low birth weight is associated with a range of socio-economic and genetic characteristics of families and their children. For example, LBW infants are more likely to be born to poor families. Black et al. (2007) devise a novel technique to disentangle the effect o low birth weight from other socio-economic characteristics of the household in which the child is born.

The extant literature, however, does not pay commensurate attention to the impact of BMI on employment prospects and wages earned by workers in public workfare programs. Doing this is particularly important in the context of an economy like India's where there is widespread unemployment and underemployment and where workfare is being seen as a key policy measure to combat unemployment.

According to latest available figures (for the $61^{\text {st }}$ Round of the National Sample survey conducted in 2004-05), the rate of unemployment in rural India on a currant daily status basis was 8.9 percent of the labor force (Ministry of Finance, Government of India, 2009). In addition to this open unemployment, there is considerable underemployment in rural India. Policymakers considered a strategy of enhanced employment important for its own sake as for redressing the stubbornly high incidence of poverty in rural India. The National Rural Employment Guarantee Act (NREGA) of 2005 was a direct response to these indices of deprivation in rural India and represents, perhaps, the most significant social policy initiative in India in the last decade. The NREGA states that,

[its main objective is] to provide enhancement of livelihood security of the households in rural areas of the country by providing at least 100 days of guaranteed wage employment to every household in unskilled manual work. (Ministry of Law and Justice, 2005)

This commitment is clearly a landmark event in the history of rural development policies in India. 
This paper is the first to address the critical issues of the role of BMI in influencing participation in NREG programs, determination of hours worked and wages earned. In doing so it uses a unique household panel data set collected by the authors for the Indian state of Rajasthan, The plan of this paper is as follows. Section II discusses the data set used. Section III elaborates on the methodology and discusses the principal results. Section IV concludes and provides some policy prescriptions.

\section{Data}

The present analysis draws upon household data drawn from rural Rajasthan collected during a survey conducted in 2009-10. The modus operandi for collecting the data was as follows. First, a list of NREGS districts was compiled and from these districts, three were selected on the basis of probability proportional to size (in this case, rural population as reported in the 2001 Census). In the next stage, twenty five villages were selected randomly from these three districts and from each selected village twenty households were drawn randomly. This leads to a sample of 500 households. Finally, information on individual members of those households was collected. The mode of interview was a structured questionnaire prepared for various levels such as gram panchayats, villages, households and individuals. The data contain detailed information on individual characteristics such as gender, age, education, occupation, height, weight, NREG participation ${ }^{2}$, duration of work and annual earnings, among others. At the household level, the survey collects information on social group, religion, land holding, household size and composition, PDS participation, type of ration card, among others. At the village level, the data provide information on village infrastructure, wage rates, among others.

The questionnaires were fielded by investigator who were trained by us and acquainted with the objectives and methodology of this project. When appropriate, female investigators were employed to solicit accurate information.

\section{Results}

\section{(i) BMI and Population}

Table 1 depicts some basic characteristics of the sampled population for the year 2009-10.

\footnotetext{
${ }^{2}$ An individual is said to be a NREGS participant if he/she has worked for sometime under NREGS in the past one year.
} 


\section{Table 1 here}

51 percent of the respondents were males and 49 percent females. Among females, 58.47 percent had their BMI in the normal range, followed by 37 percent underweight and 5 percent overweight. Among males, a similar pattern exists. About 54 percent of males had normal weight, 41 percent were underweight and remaining 5 percent were overweight.

About two-thirds of the population was equally distributed in the age-groups below 16 years and between 30-60 years. About one-fourth of the population was in the age group 16-30 years and about 8 percent were elderly (>60 years). In the age group less than 16 years, more than three-fourths (about 77 percent) were underweight, followed by 14 percent with normal weight and 9 percent overweight. Across all age groups, the majority of the population was normal, followed by those underweight and overweight. In the underweight population, the proportion of children ( $<16$ years) was the highest (about 64 percent) and that of elderly was the lowest (about 7 percent). Among all normal-weight persons, the proportion in the age group 30-60 years was the highest (about 47 percent), followed by those 16-30 years (about 36 percent), elderly (about 9 percent) and children (about 8 percent). Among all overweight persons, children had the highest proportion (about 61 percent).

About 40 percent of the population was illiterate. There is no clear pattern in the distribution of underweight, normal and overweight population by their education level. The proportion of population underweight or overweight declined sharply with higher education level. However, for those with normal weight, it first dropped for illiterate until secondary education level and then rose slightly for education levels higher secondary and above.

Going by social group, about one-third the population was Scheduled Tribes (ST), followed by slightly lower proportions of Other Backward Castes (OBC), one-fourth Scheduled Castes (SC) and about 11 percent 'Others'. Among all underweight persons, about 33 percent were ST, 30 percent OBC, about 27 percent SC and remaining 10 percent 'Others'. Among those with BMI in the normal range OBC had the largest representation (33 percent), followed by ST (about 32 percent), SC (about 23 percent) and 'Others' (11 percent). Among the overweight population, the proportion of OBCs was about 41 percent, followed by ST (about 24 percent), SC (about 23 percent) and 'Others’ (about 12 percent). 
63 percent of the sampled population was poor, of which 48 percent were acutely poor and 15 were moderately poor. Out of the poor, 42 percent were underweight and about 5 percent were overweight.

28 percent of individuals were from landless households and about 7 percent from households owning 0-1 acre of land. About 52 percent of the population came from households owning 1-5 acres land and the remaining 13 percent had more than 5 acres of land. In the underweight population, the proportion of landless was the highest (about 32 percent). However, in the normal population, the proportion of land holding group, 2-5 acres, was highest (about 33 percent). Moreover, the proportion of landless in the overweight population was the highest (about 38 percent).

About 24 percent of the population were from households with 4 or fewer members, 62 percent from households with 5 to 8 members and the remaining 14 percent were from larger households (>8 members). By household size group, the share of population in each of the underweight, normal and overweight categories was nearly the same.

Basic characteristics of the population by BMI are shown in Table 2.

\section{Table 2 here}

Males had lower BMI than females. BMI increased significantly with age of individuals. However, this effect weakened at older ages and the marginal effect of age on BMI turns negative after controlling for non-linear quadratic term at the mean age.

BMI was higher for married adults, as compared to those unmarried, divorced and widowed. There were no significant effects of education level and social group of households on BMI. BMI of adults increased with increased household income but weakened at higher levels of income. Moreover, the elasticity of BMI with respect to household income (computed at the mean household income after taking into account the quadratic relation) is positive.

BMI of adults is positively associated with size of households but this effect is weaker for larger households. Moreover, the elasticity of BMI with respect to household size (computed at the mean household size after taking into account the quadratic term) was negative. Adults living in villages with higher land per household have significantly higher BMI. However, 
BMI was lower for villages with higher inequality in the distribution of land holding. The model is validated by an F-test at the 1 percent level of significance.

Results from an ordered probit estimation for factors associated with different BMI categories are documented in Table 3. It contains both coefficient estimates and corresponding marginal effects for all the three BMI categories: underweight, normal and overweight. As the marginal effects are more meaningful, we shall confine our comments to them. The specification is validated by the Wald chi-square test at the 1 percent level of significance.

\section{Table 3 here}

The probability of males being underweight was higher than that for females. However, the opposite holds for those who are normal or overweight where probabilities for the males being normal or overweight are lower than for the females.

The effect of age is insignificant. As compared to unmarried, divorced and widowed individuals, married adults had lower probability of being underweight and, consequently, higher probabilities of being normal and overweight.

There were no significant effects of education levels, as compared to illiterates, except for those with middle class education. The likelihood of being underweight was significantly lower and being normal and overweight was significantly higher for those who passed middle school education. Household social groups did not have a significant effect on being underweight, normal or overweight. The probability of adults being normal and overweight increased with increased household income and family sizes but these effects weakened at higher income levels and family/household size. However, the increased proportion of adults in the household did not have a significant effect on the probabilities of adults being underweight or normal or overweight. Higher inequality in the distribution of land holdings at the village level significantly increased proportion of normal and overweight (and decreased proportion of underweight) in the adult population.

The model specification is validated by the Wald Chi-square test at 1 percent level of significance.

\section{(ii) BMI and Participation}

Basic characteristics of participation and its association with BMI are given in Table 4. 


\section{Table 4 here}

About 17 percent of the population participated in NREGS in 2009-10, out of which the proportions of underweight, normal and overweight were 24.31, 74.33 and 1.36 percent, respectively. The proportions of male and female participants in their respective populations were, respectively, 12 percent and 22 percent. Among NREGS participants, about 64 percent were females with 36 percent males.

Among female participants, 71 percent had their BMI in the normal range and the proportions of underweight and overweight were 27 percent and 2 percent, respectively. Among male participants, about 81 percent had normal weight, 19 percent were underweight and none were overweight. About 77 percent of the participants were in the age group 30 to 60 years.

About 66 percent of the participants were illiterate, and the share of participants declined with higher education level. Further, all the overweight participants were illiterate. Going by social group, shares of participants of SC, ST, OBC and 'Others' broadly corresponded to their respective shares in the total population (as in Table 1). However, among the underweight participants, the proportion of OBCs was the highest (about 33 percent), followed by SC (about 32 percent), ST (about 28 percent) and 'Others' (about 7 percent). Among the overweight, the proportion of SC was the highest (about 93 percent), followed by OBC (about 7 percent). None of the participants from ST and 'Others' was overweight.

Poverty status and nutrition status of population are closely linked. Among those that were non-poor (poor) the proportions of NREGS participants were about 10 (21) percent. However, among the participants, the proportion of poor individuals was as high as threefourths. Among poor participants, 26 percent were underweight, about 2 percent were overweight and the remaining 73 percent had normal weight. Moreover, the share of underweight participants declined steadily from those acutely poor to affluent, suggesting that the share of underweight decreased with increased levels of income. Interestingly, all overweight participants are from poor households. Among NREGS participants, 23 percent were landless, about 10 percent had land holdings in the $0-1$ acre range, 19 percent had land holdings between 1-2 acres, 37 percent owned 2-5 acres land, and the remaining 11 percent had land owned more than 5 acres. Among landless participants, about 38 percent were underweight, 57 percent had normal weight and 5 percent were overweight. By household size, about 39 percent participants were from households with 4 or fewer members, 49 
percent from households with 5-8 members and the remaining 12 percent were from larger households ( $>8$ members). Results are given in Table 5.

\section{Table 5 here}

The mean BMI for participants and non-participants is 19.88 and 20.25, respectively. Similarly, median BMI for participants and non-participants is 20.04 and 20.12, respectively. BMI of non-participants are more dispersed than those of participants. The T-test for difference of mean BMI of participants and non-participants suggests that there are significant differences at 10 percent level of significance: BMI for non-participants is significantly higher than that for participants. However, the sign test for median differences between participants and non-participants suggests that these differences are not significant.

The first order stochastic dominance test for BMI of participants and non-participants is inconclusive (Figure 1). For BMI below 22, the two CDFs overlap and the stochastic dominance of participants over non-participants is not clear. However, in the range 22 to 27 (approximately), the CDF for non-participants is below that for participants. This suggests that in this range non-participants dominate over participants, implying lower fractions of the latter in the normal BMI range. Going by poverty status of participants, it follows from figure 2 that, over almost the entire normal BMI range, non-poor participants dominate poor participants, implying lower proportions of the former.

\section{Table 6 and Figures 1 and 2 here}

Probit estimates for factors associated with participation under NREGS are reported in Table 6. We report results for two different probit specifications. In specification 1 , predicted BMI obtained from robust regression estimates in Table 2 are used, whereas in specification 2, predicted probabilities of normal and overweight obtained from ordered probit estimates in Table 3 are used, with underweight as the reference group. Both coefficient estimates and their marginal effects were reported for each of the specifications. As the marginal effects are more meaningful (Greene, 2003), we shall confine our comments to them. The results in both the specifications were validated by the Wald chi-square test at the 1 percent level of significance.

In specification 1, there was no significant difference in the participation of males and female. However, specification 2 suggests that males tend to participate less than females. 
Age of individuals did not have a significant effect on NREGS participation. In specification 1, the higher the predicted BMI, the higher was the propensity to participate in NREGS. Similarly, the marginal effect in specification 2 showed that probability of NREGS participation increased significantly with increase in the predicted probability of being normal. In contrast, the probability of being overweight significantly reduced the likelihood of NREGS participation.

Illiterates tended to participate more than those who were literate (i.e. those with at least primary education). Individuals from SC, ST and OBC groups had higher probabilities of participation in NREGS, compared to 'Others'. However, the marginal effects for SCs and STs were significantly weak in specification 1 and that of the former was insignificant in specification 2.

The probability of participation in NREGS declines with amount of land-owned. However, this result is significant only at the 10 percent in specification 1 and only weakly significant in specification 2. Participation probabilities were significantly lower for members of relatively larger households. The effect of household size weakened at higher levels.

As expected, the propensity to participate in NREGS increased with increase in the ratio of NREGS wage to the agriculture wage rate and fell with increased inequality in the distribution of land holdings at the village level.

Table 7 depicts some key statistics for days worked under NREGS by participants of different BMI categories.

\section{Table 7 here}

The mean and median days worked under NREGS were highest for normal, followed by underweight and lowest for overweight participants. The coefficient of variation (which takes into account both mean and standard deviation) confirms that variability in the duration of work for overweight participants was highest, followed by underweight and normal participants.

To further examine the relationships between duration of participation and BMI, a stochastic dominance test is employed (Figure 3). 


\section{Figure 3 here}

\section{(iii) BMI and Duration of Work under NREGS}

Since CDFs of days worked under NREGS by overweight participants lie above CDFs of days worked by underweight and normal participants, the latter dominated. This means that duration of work for overweight participants was lower than that of underweight and normal participants.

At lower duration of work CDFs for underweight and normal participants did not exhibit clear stochastic dominance. However, normal participants clearly dominate underweight participants when spells are longer-in particular, more than 50 days of work. Thus, underweight participants worked for fewer days as compared to normal participants.

Tobit estimates for factors associated with number of days worked by NREGS participants in one year prior to the survey are reported in Table 8. Based on two different sets of NREGS participation at the village level and BMI estimates in the earlier sections, we had reported results for two different Tobit specifications. In specification 1, predicted probability of village level NREGS participation obtained from specification 1 of probit estimates in Table 6 and predicted BMI obtained from robust regression estimates in Table 2 are used; in specification 2, predicted probability of village level NREGS participation obtained from specification 2 of probit estimates in Table 6 and predicted probabilities of normal and overweight obtained from ordered probit estimates in Table 3 are used, with underweight as the reference group. Further, both coefficient estimates and marginal effects are reported for each of the specifications. However, we shall confine our comments to the marginal effects. The results in both the specifications were validated by the F-test at the 1 percent level of significance.

\section{Table 8 here}

Males tended to work fewer days than females. Age of individuals did not have a significant effect. The higher the village level participation in NREGS, the higher is the duration of work for individual participants. Duration of work in NREGS increased with increase in BMI of participants (specification 1). Moreover, as compared to underweight participants, while number of days worked in NREGS was higher for those with normal weight, it was lower for those who were overweight. 
While illiterates tended to work more days in a year than those with at least primary level education, there was no significant difference between illiterates and middle school level participants. As compared to participants from 'Others', participants from ST and OBC social groups tended to work significantly longer spells (though this effect is only weakly significant). However, there was no significant difference between SC and 'Others'. Participants with higher land holdings in the household worked significantly more days (only specification 1). The larger the family size, the lower was the duration of work. However, this effect weakened among larger households.

\section{(iv) BMI and NREGS Earnings}

Table 9 depicts some key statistics for earnings under NREGS by participants of different BMI categories.

\section{Table 9 here}

The mean and median annual earning were highest for normal, followed by underweight and lowest for the overweight participants. The coefficient of variation also confirms that variability in the earnings for overweight participants was highest, followed by underweight and normal participants.

To further examine the links between BMI and earnings, we use stochastic dominance test (Figure 4).

\section{Figure 4 here}

As CDFs of annual NREGS wage earnings for overweight participants lie above the CDFs for underweight and normal participants, the latter dominate implying that earnings for overweight participants are lower than the earnings of underweight and normal weight participants.

CDFs NREGS wage earnings for underweight and normal weight participants do not suggest dominance of one over the other at lower amounts. However, normal weight participants clearly dominate over underweight participants when earnings exceed Rs 5200.

Tobit estimates for factors associated with annual wage earnings by NREGS participants are reported in Table 10. We use two different specifications. In specification 1, predicted probability of village level NREGS participation obtained from specification 1 of Probit 
estimates in Table 6 and predicted BMI obtained from robust regression estimates in Table 2 are used; in specification 2, predicted probability of village level NREGS participation obtained from specification 2 of Probit estimates in Table 6 and predicted probabilities of normal and overweight obtained from ordered Probit estimates in Table 3 are used, with underweight as the reference group. Both coefficient estimates and marginal effects are reported for each specification. However, we shall confine our comments to the marginal effects. The results in both the specifications were validated by the F-test at the 1 percent level of significance.

\section{Table 10 here}

Males earned significantly less than females. Age of individuals did not have a significant effect. Earnings of NREGS participants increased with increase in the village level probability of participation. Earnings also increased with increase in BMI of participants (specification 1). Moreover, as compared to underweight participants, while NREGS earnings were higher for those with normal weight, it was lower for those who were overweight.

While illiterates earned more than those who were literate, with primary, secondary, or higher secondary and above education levels, there was no significant difference between illiterates and middle school level participants. Participants from ST and OBC social groups tended to earn significantly more (only weakly significant) than those from 'Others'. However, there was no significant difference between SC and Others. Earnings of participants decreased with increased household land holdings (only in specification 1). The larger the family size, the lower were the earnings. However, this effect weakened among larger households.

\section{Conclusions}

Despite its evident importance relatively little is known about links between BMI and participation in workfare programs, particularly in India. This paper has attempted to fill this void and examined the association between BMI and participation in, duration of employment in and earnings from employment in NREGs. Thus we go beyond the scope of the extant literature and model these links for both male and female workers with varied social and economic backgrounds. Further, we permit non-linearities in some impacts and allow for mutual endogenity, say between BMI and earnings. To the best of our knowledge this is the first paper to examine this range of issues. 
A complex pattern of associations of BMI with participation in, duration of employment in and earnings from the NREGs emerges. The higher the predicted BMI, the higher was the propensity to participate in NREGS. Similarly, the marginal effect in specification 2 showed that probability of NREGS participation increased significantly with increase in the predicted probability of being normal. By contrast, the probability of being overweight significantly reduced the likelihood of NREGS participation. Hence, even a workfare program like the NREGS shows a preference for workers with BMI in the normal range. Consequences for hours worked and earnings follow from this.

A policy insight of considerable importance is that to the extent that acutely poor overlap with the underweight, their prospects of climbing out of poverty are bleaker than those of moderately poor and other (relatively) affluent, as they are less likely to participate in NREGS, work long spells and earn large amounts.

\section{References:}

Baland, J. M, Dreze, J, \& Leruth, L. (1996) "Daily Wages and Piece Rates in Agrarian Economies”, London: STICERD, London School of Economics, mimeo.

Black, S. Devereux, P. and K. Salvanes (2007) "From the Cradle to the Labor Market: the Effect of Birth Weight on Adult Outcomes" Quarterly Journal of Economics, 122(1), 409-439.

Cawley, J. (2000) “Body Weight and Women’s Labor Market Outcomes” NBER Working Paper \#W7841

Deolalikar, A. (1988) "Nutrition and Labor Productivity in Agriculture: Estimates for Rural South India”, Review of Economics and Statistics, 70, 406-413.

Greene, W. H (2003). Econometric Analysis. $5^{\text {th }}$ Edition, Delhi, Pearson Education, India.

Greve, J. (2007) “Obesity and Labor Market Outcomes: New Danish Evidence” Working Paper 200713, Aarhus School of Business, Department of Economics.

Han, E., Norton, E. and S. Stearns (2009) "Weight and Wages: fat vs. lean paychecks” Health Economics, 18(5), 535-548.

Ministry of Finance, Government of India (2009) Economic Survey of the Government of India, New Delhi.

Ministry of Law and Justice, Government of India (2005) National Rural Employment Guarantee Act 2005.

Preker, A., Scheffler, R. and M. Bassett (2007) Private Voluntary Health Insurance in Development: Friend or Foe? Washington DC: The World Bank.

Strauss, J. (1986) “Does better nutrition raise farm productivity?” Journal of Political Economy, 94(2), 297-320.

Thomas, D. and J. Strauss (1997) "Health and Wages: Evidence on men and women in urban Brazil" Journal of Econometrics, 77(1), 159-185. 
Table 1

Percentage Distribution of Population in Different Body Mass Index Categories by their Individual and Household Characteristics in Rajasthan: 2009-10

\begin{tabular}{|c|c|c|c|c|}
\hline \multirow{2}{*}{ Characteristics } & \multirow{2}{*}{$\begin{array}{l}\text { Share (\%) in } \\
\text { population }\end{array}$} & \multicolumn{3}{|c|}{$\%$ population who are } \\
\hline & & Underweight & Normal & Overweight \\
\hline \multicolumn{5}{|l|}{ Gender } \\
\hline Female & 48.95 & $37.03(48.66)$ & $58.47(53.03)$ & $4.50(47.45)$ \\
\hline Male & 51.05 & $40.78(51.34)$ & $54.03(46.97)$ & $5.20(52.55)$ \\
\hline \multicolumn{5}{|l|}{ Age-group (in years) } \\
\hline$<16$ & 33.52 & 77.07(63.49) & $13.66(7.77)$ & $9.27(61.34)$ \\
\hline$\geq 16-<30$ & 25.49 & $23.08(15.61)$ & $76.00(35.50)$ & $0.92(5.02)$ \\
\hline$\geq 30-<60$ & 33.28 & $16.58(14.28)$ & 79.54(47.30) & $3.88(26.87)$ \\
\hline$\geq 60$ & 7.71 & $31.32(6.61)$ & $64.70(9.43)$ & $3.99(6.76)$ \\
\hline \multicolumn{5}{|l|}{ Education Level } \\
\hline Illiterate & 40.23 & $33.10(34.26)$ & $60.94(43.55)$ & $5.96(49.57)$ \\
\hline Literate but up to primary & 27.57 & $47.08(32.57)$ & $46.42(22.17)$ & $6.50(36.09)$ \\
\hline Middle & 13.51 & 52.85(19.12) & $45.38(11.34)$ & $1.78(5.17)$ \\
\hline Secondary & 7.15 & $39.12(7.10)$ & $57.42(7.19)$ & $3.46(5.04)$ \\
\hline Higher secondary and above & 11.55 & $22.95(6.95)$ & $75.35(15.76)$ & $1.70(4.14)$ \\
\hline \multicolumn{5}{|l|}{ Social Group } \\
\hline SC & 24.83 & $42.07(26.57)$ & $53.35(23.26)$ & $4.58(23.22)$ \\
\hline ST & 32.73 & $39.77(32.97)$ & $56.60(32.40)$ & $3.63(24.18)$ \\
\hline OBC & 31.86 & $36.33(30.18)$ & $57.57(33.02)$ & $6.10(40.70)$ \\
\hline Others & 10.57 & $36.50(10.29)$ & 58.24(11.33) & $5.26(11.90)$ \\
\hline \multicolumn{5}{|l|}{ Poverty Status } \\
\hline Acutely poor & 47.83 & $43.36(52.58)$ & $51.19(42.86)$ & $5.45(53.08)$ \\
\hline Moderately poor & 15.20 & $37.85(15.07)$ & $58.80(16.16)$ & $3.36(10.73)$ \\
\hline Moderately non-poor & 17.11 & $39.38(16.98)$ & $58.57(17.43)$ & $2.05(7.11)$ \\
\hline Affluent & 19.87 & $28.95(15.37)$ & $64.23(23.55)$ & $6.82(29.09)$ \\
\hline Non-poor & 36.98 & $33.62(32.35)$ & $61.69(40.98)$ & $4.68(36.20)$ \\
\hline Poor & 63.02 & $42.00(67.65)$ & $53.07(59.02)$ & $4.93(63.80)$ \\
\hline \multicolumn{5}{|l|}{ Land owned group (in acres) } \\
\hline Landless & 27.92 & 42.81(31.92) & $50.77(26.13)$ & $6.42(38.44)$ \\
\hline$>0-\leq 1$ & 7.45 & $35.33(6.95)$ & $62.29(8.46)$ & $2.38(3.76)$ \\
\hline$>1-\leq 2$ & 19.49 & $42.15(20.69)$ & $55.23(18.72)$ & $2.63(10.35)$ \\
\hline$>2-\leq 5$ & 31.91 & $37.60(30.36)$ & $58.91(32.83)$ & $3.49(22.63)$ \\
\hline$>5$ & 13.23 & $30.33(10.08)$ & $60.38(13.86)$ & $9.30(24.82)$ \\
\hline \multicolumn{5}{|l|}{ Household Size } \\
\hline 4 and less & 23.74 & $36.77(22.63)$ & $58.69(24.93)$ & $4.54(22.44)$ \\
\hline$>4-\leq 8$ & 62.01 & 40.04(63.92) & $55.35(61.00)$ & $4.61(59.06)$ \\
\hline$>8-\leq 12$ & 13.83 & $37.00(12.99)$ & $56.65(13.73)$ & 6.34(17.89) \\
\hline$>12$ & 0.43 & $45.07(0.46)$ & $47.49(0.33)$ & $7.43(0.60)$ \\
\hline$A I I$ & 100.00 & $38.86(100.00)$ & $56.30(100.00)$ & $4.84(100.00)$ \\
\hline
\end{tabular}

Note: Figures in bracket are the column percentages. For definition of underweight, normal weight and overweight ranges, see Table A.1 in the annex. For definitions of severity of poverty, see Table A.2 in the annex. 
Table 2

Factors Associated with Body Mass Index of Adult Population in Rajasthan: Robust Regression Estimates

\begin{tabular}{|c|c|c|}
\hline Dependent Variable & Body Ma & \\
\hline Explanatory Variables & Coefficient(t-value) & Elasticity \\
\hline Gender & $-0.36^{\star \star \star}(-2.91)$ & -0.01 \\
\hline Age & $0.07^{\star \star \star}(3.36)$ & 0.14 \\
\hline Square of age & $-0.001^{\star \star \star}(-3.35)$ & -0.07 \\
\hline Marital status: Married & $0.53^{\star \star \star}(3.28)$ & 0.02 \\
\hline Primary education & $0.23(1.48)$ & 0.00 \\
\hline Middle school & $0.16(0.75)$ & 0.00 \\
\hline Secondary education & $0.10(0.41)$ & 0.00 \\
\hline Higher secondary and above & $0.23(1.03)$ & 0.00 \\
\hline SC & $0.004(0.01)$ & 0.00 \\
\hline ST & $0.26(0.98)$ & 0.00 \\
\hline OBC & $0.06(0.23)$ & 0.00 \\
\hline Ratio of PCME to Poverty Line & $1.20^{\star \star *}(6.00)$ & 0.06 \\
\hline Square of Ratio of PCME to Poverty Line & $-0.17^{\star \star \star}(-5.50)$ & -0.01 \\
\hline Household size & $0.16^{\star \star}(2.37)$ & 0.05 \\
\hline Square of household size & $-0.01^{\star *}(-2.33)$ & -0.02 \\
\hline Land per household in the village & $0.22^{\star \star \star}(2.96)$ & 0.05 \\
\hline Land Gini index & $1.80^{\star * \star(3.24)}$ & 0.04 \\
\hline Interaction of land per household and land Gini index at the village level & $-0.27^{\star \star}(-2.13)$ & -0.03 \\
\hline Constant & 15.42 & \\
\hline Number of observations & 1635 & \\
\hline$F(18,1616)$ & $7.68^{\star \star \star}$ & \\
\hline Predicted BMI & & 20.01 \\
\hline
\end{tabular}

Note: ${ }^{* \star},{ }^{* *,}$, refer to significance at the $1 \%, 5 \%$ and $10 \%$ level, respectively. After controlling for quadratic or interaction terms, the actual elasticity of age, ratio of household PCME to state poverty line, household size, land per household in the village and village land gini index at the mean values were $-4.71,0.05,-0.07,0.04$, and -0.09 , respectively. Definitions of the variables used in the analysis are given in Table A.3 in the annex. 
Table 3

Factors associated with Different BMI categories: Ordered probit estimates

\begin{tabular}{|c|c|c|c|c|}
\hline \multirow{3}{*}{$\begin{array}{l}\text { Dependent variable } \\
\text { Explanatory variables }\end{array}$} & \multicolumn{4}{|c|}{ BMI categories: 1=Underweight, 2=Normal, and 3=Overweight } \\
\hline & \multirow{2}{*}{$\begin{array}{l}\text { Coefficient } \\
\text { (z-value) }\end{array}$} & \multicolumn{3}{|c|}{ Marginal Effects (z-value) for } \\
\hline & & Underweight & Normal & Overweight \\
\hline Gender & $-0.24^{\star *}(-2.26)$ & $0.06^{\star \star}(2.26)$ & $-0.05^{\star \star}(-2.27)$ & $-0.01 * *(-2.01)$ \\
\hline Age & $0.02(1.27)$ & $-0.01(-1.27)$ & $0.01(1.27)$ & $0.00(1.26)$ \\
\hline Square of age & $0.00(-1.22)$ & $0.00(1.22)$ & $0.00(-1.21)$ & $0.00(-1.22)$ \\
\hline Marital status: Married & $0.32^{\star *}(2.42)$ & $-0.09 * \star(-2.28)$ & $0.08^{\star \star}(2.22)$ & $0.01 * *(2.36)$ \\
\hline Primary education & $0.09(0.72)$ & $-0.02(-0.74)$ & $0.02(0.75)$ & $0.00(0.67)$ \\
\hline Middle school & $0.24 w(1.53)$ & $-0.06^{\star}(-1.68)$ & $0.05^{\star}(1.84)$ & $0.01 *(1.23)$ \\
\hline Secondary education & $-0.19(-0.81)$ & $0.06(0.76)$ & $-0.05(-0.74)$ & $-0.01(-1.00)$ \\
\hline Higher secondary and above & $-0.17(-0.92)$ & $0.05(0.88)$ & $-0.04(-0.85)$ & $-0.01(-1.03)$ \\
\hline SC & $0.04(0.19)$ & $-0.01(-0.19)$ & $0.01(0.19)$ & $0.00(0.19)$ \\
\hline ST & $0.22(1.17)$ & $-0.06(-1.21)$ & $0.05(1.24)$ & $0.01(1.08)$ \\
\hline $\mathrm{OBC}$ & $-0.04(-0.21)$ & $0.01(0.21)$ & $-0.01(-0.21)$ & $0.00(-0.21)$ \\
\hline Ratio of PCME to Poverty Line & $0.63^{\star \star \star}(4.02)$ & $-0.17^{\star \star \star}(-4.04)$ & $0.14^{\star \star \star}(3.89)$ & $0.03^{\star \star \star}(3.42)$ \\
\hline $\begin{array}{l}\text { Square of Ratio of PCME } \\
\text { to Poverty Line }\end{array}$ & $-0.05^{\star \star}(-2.25)$ & $0.01 * *(2.26)$ & $-0.01 * *(-2.22)$ & $-0.002^{\star *}(-2.15)$ \\
\hline Household size & $0.19 * \star \star(3.41)$ & $-0.05^{\star \star \star}(-3.43)$ & $0.04^{\star \star \star}(3.41)$ & $0.01 * \star \star(2.81)$ \\
\hline Square of household size & $-0.01^{\star \star \star}(-3.05)$ & $0.003^{\star * \star(3.06)}$ & $-0.002^{\star \star *}(-3.05)$ & $-0.0004^{\star \star *}(-2.56)$ \\
\hline Land per household in the village & $0.02(1.09)$ & $0.00(-1.08)$ & $0.00(1.07)$ & $0.00(1.10)$ \\
\hline Land Gini index & $0.57^{\star \star}(2.15)$ & $-0.15^{\star \star}(-2.22)$ & $0.13^{\star \star}(2.23)$ & $0.03^{\star \star}(1.95)$ \\
\hline /cut1 & 1.50 & & & \\
\hline /cut2 & 4.46 & & & \\
\hline Number of observations & 1635 & & & \\
\hline Wald chi-square(17) & $73.76^{\star \star \star}$ & & & \\
\hline Pseudo R-square & 0.0744 & & & \\
\hline Log-pseudolikelihood & -955.96419 & & & \\
\hline Predicted Probability & & 0.19 & 0.79 & 0.02 \\
\hline
\end{tabular}

Note: ${ }^{* \star},{ }^{* *},{ }^{*}$ refer to significance at the 1\%,5\% and 10\% level, respectively; and w denotes weakly significant (>10\% level). Figures in parentheses are the z-values and based on robust standard errors. After controlling for quadratic terms, actual marginal effects of ratio of household PCME to state poverty line and household size in the underweight category were -0.15 and -0.02 , respectively. After controlling for the quadratic terms, actual marginal effects of ratio of household PCME to state poverty line and household size in the normal category were 0.12 and 0.02 , respectively. After controlling for the quadratic terms, actual marginal effects of ratio of household PCME to state poverty line and household size in the overweight category were 0.02 and 0.003 , respectively. Definitions of the variables used in the analysis are given in Table A.3 in the annex. 
Table 4

Percentage Distribution of Underweight, Normal and Overweight NREGS Participants by their individual and household characteristics

\begin{tabular}{|c|c|c|c|c|}
\hline \multirow{2}{*}{ Characteristics } & \multirow{2}{*}{$\begin{array}{c}\text { Share }(\%) \text { in NREGS } \\
\text { participation }\end{array}$} & \multicolumn{3}{|c|}{$\%$ of Participants who are } \\
\hline & & Underweight & Normal & Overweight \\
\hline \multicolumn{5}{|l|}{ Gender } \\
\hline Female & 21.95(63.74) & $26.82(73.32)$ & 71.14(63.62) & $2.04(100.00)$ \\
\hline Male & $11.55(36.26)$ & 19.34(26.68) & $80.66(36.38)$ & $0.00(0.00)$ \\
\hline \multicolumn{5}{|l|}{ Age group (in years) } \\
\hline$\geq 16-<30$ & 7.83(18.14) & $27.54(20.61)$ & 71.04(17.38) & 1.42(19.03) \\
\hline$\geq 30-<60$ & $25.51(77.16)$ & $23.58(74.81)$ & $74.99(77.80)$ & $1.42(80.97)$ \\
\hline$\geq 60$ & $6.71(4.70)$ & $23.75(4.59)$ & $76.25(4.82)$ & $0.00(0.00)$ \\
\hline \multicolumn{5}{|l|}{ Education Level } \\
\hline Illiterate & $25.32(65.85)$ & $24.27(67.40)$ & $73.72(66.94)$ & $2.01(100.00)$ \\
\hline Literate but up to primary & 13.61(17.18) & $24.21(15.47)$ & $75.79(15.84)$ & $0.00(0.00)$ \\
\hline Middle & $14.48(9.03)$ & $14.61(5.73)$ & $85.39(10.96)$ & $0.00(0.00)$ \\
\hline Secondary & $5.78(3.04)$ & $34.61(3.49)$ & $65.39(2.16)$ & $0.00(0.00)$ \\
\hline Higher secondary and above & $4.76(4.89)$ & $38.68(7.91)$ & $61.32(4.10)$ & $0.00(0.00)$ \\
\hline \multicolumn{5}{|l|}{ Social Group } \\
\hline SC & $17.16(25.26)$ & $32.10(31.65)$ & $62.65(20.20)$ & $5.24(92.70)$ \\
\hline ST & $17.99(32.41)$ & $21.65(28.30)$ & $78.35(33.50)$ & $0.00(0.00)$ \\
\hline OBC & $17.76(36.91)$ & $20.57(32.79)$ & $79.17(41.27)$ & $0.26(7.30)$ \\
\hline Others & $7.84(5.42)$ & $32.08(7.26)$ & $67.92(5.03)$ & $0.00(0.00)$ \\
\hline \multicolumn{5}{|l|}{ Poverty Status } \\
\hline Acutely poor & $21.06(54.88)$ & $25.77(56.25)$ & $71.84(51.29)$ & $2.40(93.79)$ \\
\hline Moderately poor & $20.59(20.01)$ & $24.82(21.36)$ & $74.78(21.05)$ & $0.40(6.21)$ \\
\hline Moderately non-poor & $16.36(18.19)$ & $27.31(21.03)$ & $72.69(18.30)$ & $0.00(0.00)$ \\
\hline Affluent & $5.11(6.91)$ & $4.54(1.36)$ & $95.46(9.36)$ & $0.00(0.00)$ \\
\hline Non-poor & $10.19(25.10)$ & 20.93(22.39) & $79.07(27.66)$ & $0.00(0.00)$ \\
\hline Poor & $20.93(74.90)$ & $25.50(77.61)$ & $72.67(72.34)$ & $1.83(100.00)$ \\
\hline \multicolumn{5}{|l|}{ Land owned group (in acres) } \\
\hline Landless & $14.21(23.41)$ & $37.89(36.06)$ & $57.04(17.76)$ & $5.07(86.49)$ \\
\hline$>0-\leq 1$ & $23.29(9.98)$ & $1.56(0.64)$ & $98.44(13.30)$ & $0.00(0.00)$ \\
\hline$>1-\leq 2$ & $16.23(18.67)$ & 21.82(16.90) & $78.18(19.81)$ & $0.00(0.00)$ \\
\hline$>2-\leq 5$ & $18.57(36.53)$ & $24.73(37.81)$ & $74.77(37.38)$ & $0.49(13.51)$ \\
\hline$>5$ & 13.44(11.41) & $19.28(8.58)$ & $80.72(11.75)$ & $0.00(0.00)$ \\
\hline \multicolumn{5}{|l|}{ Household Size } \\
\hline 4 and less & $24.34(39.43)$ & 23.18(38.67) & $76.82(41.91)$ & $0.00(0.00)$ \\
\hline$>4-\leq 8$ & $13.41(48.7)$ & $23.98(49.19)$ & $73.30(49.17)$ & $2.72(100.00)$ \\
\hline$>8-\leq 12$ & 14.83(11.43) & 31.32(11.73) & $68.68(8.41)$ & $0.00(0.00)$ \\
\hline$>12$ & 21.16(0.44) & $20.91(0.41)$ & $79.09(0.50)$ & $0.00(0.00)$ \\
\hline All & $16.55(100.00)$ & $24.31(100.00)$ & $74.33(100.00)$ & $1.36(100.00)$ \\
\hline
\end{tabular}

Note: Figures in brackets are the column percentages. For definition of underweight, normal weight and overweight ranges, see Table A.1 in the annex. 
Table 5: BMI and NREGS Participation: Some Key Statistics

\begin{tabular}{|c|c|c|c|c|}
\hline BMI Statistics & Non-participants & Participants & $\begin{array}{l}\text { t-test }{ }^{\wedge} \text { for difference } \\
\text { of mean BMI } \\
\text { between Participants } \\
\text { and Non-Participants }\end{array}$ & $\begin{array}{c}\text { Sign Test } \\
\text { or Median differences } \\
\text { between Participants } \\
\text { and Non-Participants } \\
\text { with continuity correction }\end{array}$ \\
\hline Mean & 20.25 & 19.88 & $\begin{array}{c}t(691.602)=1.49^{*} \\
\operatorname{Pr}=0.0683\end{array}$ & \\
\hline Median & 20.12 & 20.04 & & $\begin{array}{l}\text { Continuity corrected: Pearson } \\
\text { chi2 } 2(1)=0.1570 \mathrm{Pr}=0.692\end{array}$ \\
\hline Standard Deviation & 2.33 & 2.30 & & \\
\hline Minimum & 7.36 & 13.46 & & \\
\hline Maximum & 33.58 & 29.55 & & \\
\hline
\end{tabular}

${ }^{\wedge} t$ distribution follows Satterthwaite's degrees of freedom for unequal variances. * refers to significance at 10 percent level of significance. Sign Test for Median differences performs a nonparametric K-sample test (here $\mathrm{K}=2$ ) on the equality of medians. It tests the null hypothesis that the $\mathrm{K}$ samples were drawn from populations with the same median. For the two samples, the chi-squared test statistic is computed. 
Body Mass Index, Participation, Duration of Work and Earnings under NREGS: Evidence from Rajasthan

Table 6

Factors Associated with NREGS Participation in Rajasthan: Probit Estimates

\begin{tabular}{|c|c|c|c|c|}
\hline \multirow{3}{*}{$\begin{array}{l}\text { Dependent Variable } \\
\text { Specification } \\
\text { Explanatory variables }\end{array}$} & \multicolumn{4}{|c|}{ NREGS Participation } \\
\hline & \multicolumn{2}{|c|}{ Specification 1} & \multicolumn{2}{|c|}{ Specification 2} \\
\hline & Coeff (z-value) & $\begin{array}{l}\text { Marginal effect } \\
\text { (z-value) }\end{array}$ & $\begin{array}{c}\text { Coeff } \\
\text { (z-value) }\end{array}$ & $\begin{array}{l}\text { Marginal effect } \\
\text { (z-value) }\end{array}$ \\
\hline Gender & $-0.15(-1.39)$ & $-0.03(-1.38)$ & $-0.22^{\star}(-1.93)$ & $-0.05^{\star}(-1.90)$ \\
\hline Age & $0.00(-0.24)$ & $0.00(-0.24)$ & $0.00(0.10)$ & $0.00(0.10)$ \\
\hline BMI (IV) & $0.27^{\star \star \star}(3.58)$ & $0.06^{\star \star \star(3.53)}$ & & \\
\hline Normal (IV) & & & $2.06^{\star \star \star}(2.82)$ & $0.45^{\star \star \star}(2.83)$ \\
\hline Overweight (IV) & & & $-4.65^{\star \star}(-2.22)$ & $-1.02^{\star \star}(-2.21)$ \\
\hline Primary education & $-0.41^{\star \star \star}(-2.86)$ & $-0.08^{\star \star \star}(-3.39)$ & $-0.31^{\star *}(-2.11)$ & $-0.06^{\star *}(-2.39)$ \\
\hline Middle school & $-0.28 w(-1.51)$ & $-0.05^{\star}(-1.76)$ & $-0.26(-1.36)$ & $-0.05 w(-1.55)$ \\
\hline Secondary education & $-0.72^{\star \star \star}(-3.21)$ & $-0.11^{\star \star \star}(-5.01)$ & $-0.56^{\star \star}(-2.51)$ & $-0.09 * \star *(-3.51)$ \\
\hline Higher secondary and above & $-0.91^{\star \star \star}(-3.92)$ & $-0.14^{\star \star \star}(-6.11)$ & $-0.77^{\star \star \star}(-3.43)$ & $-0.13^{\star \star *}(-4.96)$ \\
\hline SC & $0.37^{\star}(1.73)$ & $0.09 w(1.57)$ & $0.30(1.44)$ & $0.07(1.33)$ \\
\hline ST & $0.38 \star(1.76)$ & $0.09 w(1.61)$ & $0.34 w(1.61)$ & $0.08 w(1.48)$ \\
\hline $\mathrm{OBC}$ & $0.41^{\star \star}(1.99)$ & $0.10^{\star}(1.85)$ & $0.41^{\star \star}(1.99)$ & $0.10^{*}(1.85)$ \\
\hline Land owned & $-0.02^{\star}(-1.79)$ & $-0.004^{*}(-1.78)$ & $-0.01(-1.44)$ & $0.00(-1.42)$ \\
\hline Household size & $-0.28^{\star \star *}(-4.92)$ & $-0.06^{\star \star \star}(-4.70)$ & $-0.30^{\star \star \star}(-5.12)$ & $-0.07^{\star \star *}(-5.01)$ \\
\hline Square of household size & $0.01^{\star \star \star}(4.34)$ & $0.003^{\star \star \star}(4.12)$ & $0.02 \star \star \star(4.45)$ & $0.00 \star \star \star(4.30)$ \\
\hline Ratio of NREG to AGR wage rate & $-2.25^{\star \star}(-2.55)$ & $-0.49^{\star \star \star}(-2.62)$ & $-1.97 \star \star(-2.24)$ & $-0.43^{\star \star}(-2.29)$ \\
\hline Land Gini index & $-5.00 \star \star \star(-3.29)$ & $-1.10^{\star \star \star}(-3.47)$ & $-4.38^{\star \star \star}(-2.86)$ & $-0.96 * \star(-3.00)$ \\
\hline $\begin{array}{l}\text { Interaction of Ratio of NREG to AGR } \\
\text { wage rate and Land Gini index }\end{array}$ & $5.47^{\star \star \star}(3.05)$ & $1.20 \star \star \star(3.19)$ & $4.97 \star \star \star(2.77)$ & $1.09 \star \star \star(2.88)$ \\
\hline Constant & -3.12 & & 0.63 & \\
\hline Number of observations & 1707 & & & \\
\hline Wald chi-square & $118.33^{\star \star \star}$ & & $118.61^{\star \star \star}$ & \\
\hline Pseudo R-square & 0.1110 & & 0.1106 & \\
\hline Log-pseudolikelihood & -687.48739 & & -687.81068 & \\
\hline Predicted Probability & & 0.14 & 0.14 & \\
\hline
\end{tabular}

Note: ${ }^{* \star *},{ }^{* *},{ }^{*}$ refer to significance at the $1 \%, 5 \%$ and $10 \%$ level, respectively; and $w$ denotes weakly significant (>10 \% level). Figures in the parenthesis are the $z$-values and based on robust standard errors. Specifications 1 and 2 differ in the sense that in specification 1 , predicted BMI obtained from robust regression estimates in Table 2 are used, while in specification 2, predicted probabilities of normal and overweight obtained from ordered probit estimates in Table 3 are used, with the underweight as the reference group. In specification 1, after controlling for quadratic and interaction terms, the actual marginal effect of household size, Ratio of NREG to AGR wage rate and Land Gini index on NREGS participation (computed at the mean values) were $-0.02,0.05$ and -0.05 , respectively. Similarly, in specification 2, after controlling for quadratic and interaction terms, the actual marginal effect of household size, Ratio of NREG to AGR wage rate and Land Gini index (computed at the mean values) were $-0.03,0.06$ and -0.01 , respectively. Definitions of the variables used in the analysis are given in Table A.3 in the annex. 
Table 7

Days Worked Under NREGS by Underweight, Normal and Overweight Participants: Some Key Statistics

\begin{tabular}{|l|c|c|c|}
\hline Key Statistics & Underweight Participants & Normal Participants & Overweight Participants \\
\hline Mean & 43.85 & 45.15 & 20.14 \\
\hline Median & 36 & 40 & 11 \\
\hline Standard Deviation & 30.66 & 29.33 & 17.31 \\
\hline Coefficient of Variation & 0.70 & 0.65 & 0.86 \\
\hline Minimum & 7 & 3 & 11 \\
\hline Max & 100 & 100 & 47 \\
\hline
\end{tabular}

Table 8

Factors Associated with Duration of Work in NREGS in Rajasthan: Tobit Estimates

\begin{tabular}{|c|c|c|c|c|}
\hline \multirow{3}{*}{$\begin{array}{l}\text { Dependent Variable } \\
\text { Specification } \\
\text { Explanatory Variables }\end{array}$} & \multicolumn{4}{|c|}{ Log of Number of Days Worked in NREGS } \\
\hline & \multicolumn{2}{|c|}{ Specification 1} & \multicolumn{2}{|c|}{ Specification 2} \\
\hline & Coeff (t-value) & Marginal effect(z-value) & Coeff (t-value) & Marginal effect(z-value) \\
\hline Gender & $-0.93^{*}(-1.76)$ & $-0.60 *(-1.76)$ & $-1.23^{\star *}(-2.28)$ & $-0.79 * *(-2.28)$ \\
\hline Age & $0.00(0.07)$ & $0.00(0.07)$ & $0.01(0.39)$ & $0.00(0.39)$ \\
\hline $\begin{array}{l}\text { Predicted Probability of } \\
\text { Participation at village level(I) }\end{array}$ & $23.02^{\star \star *}(4.60)$ & $14.76^{\star \star \star}(4.35)$ & & \\
\hline $\begin{array}{l}\text { Predicted Probability of } \\
\text { Participation at village level(II) }\end{array}$ & & & $20.32^{\star \star \star(3.92) ~}$ & $13.07^{\star \star \star(3.72)}$ \\
\hline BMI (IV) & $1.01^{\star \star \star}(2.67)$ & $0.65^{\star \star \star}(2.67)$ & & \\
\hline Normal (IV) & & & $8.32^{\star *}(2.38)$ & $5.35^{\star \star}(2.36)$ \\
\hline Overweight (IV) & & & $-23.80 * *(-2.40)$ & $-15.30^{\star *}(-2.38)$ \\
\hline Primary education & $-1.76^{\star \star \star}(-2.60)$ & $-1.18^{\star \star \star}(-2.45)$ & $-1.32^{\star}(-1.91)$ & $-0.88^{\star}(-1.83)$ \\
\hline Middle school & $-1.24(-1.37)$ & $-0.83(-1.30)$ & $-1.05(-1.15)$ & $-0.70(-1.11)$ \\
\hline Secondary education & $-2.98^{\star \star \star}(-2.61)$ & $-2.12^{\star \star \star}(-2.35)$ & $-2.41^{\star *}(-2.10)$ & $-1.69^{*}(-1.93)$ \\
\hline Higher secondary and above & $-4.18^{\star \star \star}(-3.75)$ & $-3.00 * * *(-3.34)$ & $-3.63^{\star \star \star}(-3.34)$ & $-2.58^{\star \star \star}(-3.00)$ \\
\hline SC & $1.49(1.41)$ & $0.92(1.46)$ & $1.19(1.15)$ & $0.74(1.19)$ \\
\hline ST & $1.66 w(1.57)$ & $1.03 w(1.62)$ & $1.53(1.48)$ & $0.96(1.53)$ \\
\hline OBC & $1.66 w(1.63)$ & $1.04 w(1.67)$ & $1.61 w(1.61)$ & $1.01^{*}(1.65)$ \\
\hline Land owned & $-0.08 w(-1.63)$ & $-0.05 w(-1.63)$ & $-0.06(-1.31)$ & $-0.04(-1.31)$ \\
\hline Household size & $-1.15^{\star \star \star}(-4.53)$ & $-0.73^{\star \star \star}(-4.51)$ & $-1.25^{\star \star \star}(-4.79)$ & $-0.81^{\star \star \star}(-4.74)$ \\
\hline Square of household size & $0.06^{\star \star \star}(3.87)$ & $0.04^{\star \star \star}(3.88)$ & $0.06^{\star \star \star}(3.97)$ & $0.04^{\star \star \star}(3.97)$ \\
\hline Constant & -23.76 & & -8.53 & \\
\hline /sigma & 5.05 & & 5.05 & \\
\hline Number of observations & 1707 & & 1707 & \\
\hline $\begin{array}{l}\text { Number of left-censored } \\
\text { observations }\end{array}$ & 1304 & & 1304 & \\
\hline $\begin{array}{l}\text { Number of uncensored } \\
\text { observations }\end{array}$ & 403 & & 403 & \\
\hline F-values & $13.11^{\star \star \star}$ & & $11.84^{\star \star *}$ & \\
\hline Pseudo R-squares & 0.0619 & & 0.0628 & \\
\hline
\end{tabular}

Note: While computing log of number of days worked in NREGS, we treat number of days worked in NREGS as $1+$ number of days worked in NREGS if number of days worked in NREGS is zero. ***, **, ${ }^{*}$ refer to significance at the $1 \%, 5 \%$ and $10 \%$ level, respectively; and $w$ denotes weakly significant ( $>10 \%$ level). All $t$ and $z$-values are based on robust standard errors. In specification 1 and 2 , the actual marginal effects of household size on duration of work after controlling for the quadratic term were -0.29 and -0.33 , respectively.

Definitions of the variables used in the analysis are given in Table A.3 in the annex. 
Body Mass Index, Participation, Duration of Work and Earnings under NREGS: Evidence from Rajasthan

Table 9

NREGS Earnings (in INR) for Underweight, Normal and Overweight Participants: Some Key Statistics

\begin{tabular}{|l|c|c|c|}
\hline Key Statistics & Underweight Participants & Normal Participants & Overweight Participants \\
\hline Mean & 2660.39 & 3045.68 & 1563.43 \\
\hline Median & 1950 & 2664 & 803 \\
\hline Standard Deviation & 1959.34 & 2014.31 & 1395.22 \\
\hline Coefficient of Variation & 0.74 & 0.66 & 0.89 \\
\hline Minimum & 350 & 192 & 803 \\
\hline Max & 7000 & 7620 & 3800 \\
\hline
\end{tabular}

Table 10

Factors Associated with NREGS Annual Wage Earnings in Rajasthan: Tobit Estimates

\begin{tabular}{|c|c|c|c|c|}
\hline \multirow{3}{*}{$\begin{array}{l}\text { Dependent Variable } \\
\text { Specification } \\
\text { Explanatory Variables }\end{array}$} & \multicolumn{4}{|c|}{ Log of NREGS Annual Wage Earnings in NREGS } \\
\hline & \multicolumn{2}{|c|}{ Specification 1} & \multicolumn{2}{|c|}{ Specification 2} \\
\hline & Coeff (t-value) & Marginal effect(z-value) & Coeff (t-value) & Marginal effect(z-value) \\
\hline Gender & $-1.97^{\star}(-1.69)$ & $-1.26^{\star}(-1.70)$ & $-2.62^{\star \star}(-2.21)$ & $-1.68^{\star \star}(-2.21)$ \\
\hline Age & $0.00(0.09)$ & $0.00(0.09)$ & $0.01(0.40)$ & $0.01(0.40)$ \\
\hline $\begin{array}{l}\text { Predicted Probability of } \\
\text { Participation at village level(I) }\end{array}$ & $49.80^{\star \star \star}(4.51)$ & $31.88^{\star \star \star}(4.26)$ & & \\
\hline $\begin{array}{l}\text { Predicted Probability of } \\
\text { Participation at village level(II) }\end{array}$ & & & $43.94^{\star \star \star}(3.83)$ & $28.21^{\star \star \star}(3.64)$ \\
\hline BMI (IV) & $2.30^{\star \star \star}(2.78)$ & $1.47^{\star \star \star}(2.77)$ & & \\
\hline Normal (IV) & & & $18.82^{\star \star}(2.44)$ & $12.08^{\star \star}(2.43)$ \\
\hline Overweight (IV) & & & $-51.48^{\star \star}(-2.37)$ & $-33.05^{\star \star}(-2.35)$ \\
\hline Primary education & $-3.86^{\star \star \star}(-2.59)$ & $-2.58^{\star \star}(-2.44)$ & $-2.88^{\star}(-1.90)$ & $-1.91^{*}(-1.82)$ \\
\hline Middle school & $-2.72(-1.37)$ & $-1.82(-1.31)$ & $-2.33(-1.17)$ & $-1.56(-1.12)$ \\
\hline Secondary education & $-6.67 * \star(-2.70)$ & $-4.75^{\star \star}(-2.43)$ & $-5.39 * *(-2.17)$ & $-3.78^{\star \star}(-1.99)$ \\
\hline Higher secondary and above & $-9.23^{\star \star *}(-3.76)$ & $-6.63^{\star \star \star}(-3.34)$ & $-8.02^{\star \star \star}(-3.33)$ & $-5.69 \star \star \star(-3.00)$ \\
\hline SC & $3.47(1.50)$ & $2.14(1.56)$ & $2.80(1.25)$ & $1.74(1.29)$ \\
\hline ST & $3.70 w(1.59)$ & $2.30 *(1.65)$ & $3.40(1.51)$ & $2.12 w(1.55)$ \\
\hline $\mathrm{OBC}$ & $3.80^{\star}(1.70)$ & $2.37^{*}(1.74)$ & $3.70 *(1.68)$ & $2.32^{\star}(1.73)$ \\
\hline Land owned & $-0.17 w(-1.59)$ & $-0.11 w(-1.59)$ & $-0.13(-1.27)$ & $-0.08(-1.27)$ \\
\hline Household size & $-2.52^{\star \star \star}(-4.53)$ & $-1.62^{\star \star \star}(-4.51)$ & $-2.78^{\star \star \star}(-4.81)$ & $-1.78^{\star \star \star}(-4.76)$ \\
\hline Square of household size & $0.13^{\star \star *}(3.88)$ & $0.08^{\star \star \star}(3.89)$ & $0.14^{\star \star *}(4.01)$ & $0.09^{\star \star *}(4.00)$ \\
\hline Constant & -53.68 & & -19.13 & \\
\hline /sigma & 11.10 & & 11.09 & \\
\hline Number of observations & 1707 & & 1707 & \\
\hline $\begin{array}{l}\text { Number of left-censored } \\
\text { observations }\end{array}$ & 1304 & & 1304 & \\
\hline $\begin{array}{l}\text { Number of uncensored } \\
\text { observations }\end{array}$ & 403 & & 403 & \\
\hline F-values & $13.40^{\star \star \star}$ & & $12.06^{\star \star \star}$ & \\
\hline Pseudo R-square & 0.0532 & & 0.0539 & \\
\hline
\end{tabular}

Note: : While computing log of wage earnings in NREGS, we treat wage earnings as $1+$ wage earnings if wage earnings is zero. ${ }^{* \star *}, * *, *$ refer to significance at the $1 \%, 5 \%$ and $10 \%$ level, respectively; and $w$ denotes weakly significant (>10 \% level). All t and $z$-values are based on robust standard errors. In specification 1 and 2, the actual marginal effects of household size on NREGS earnings after controlling for quadratic term were -0.64 and -0.72 , respectively. Definitions of the variables used in the analysis are given in Table A.3 in the annex. 
Figure 1: Cumulative Distribution Functions of Body Mass Index $\left(\mathrm{kg} / \mathrm{m}^{2}\right)$ for NREGS Participants and Non-participants in Rajasthan: 2009-10

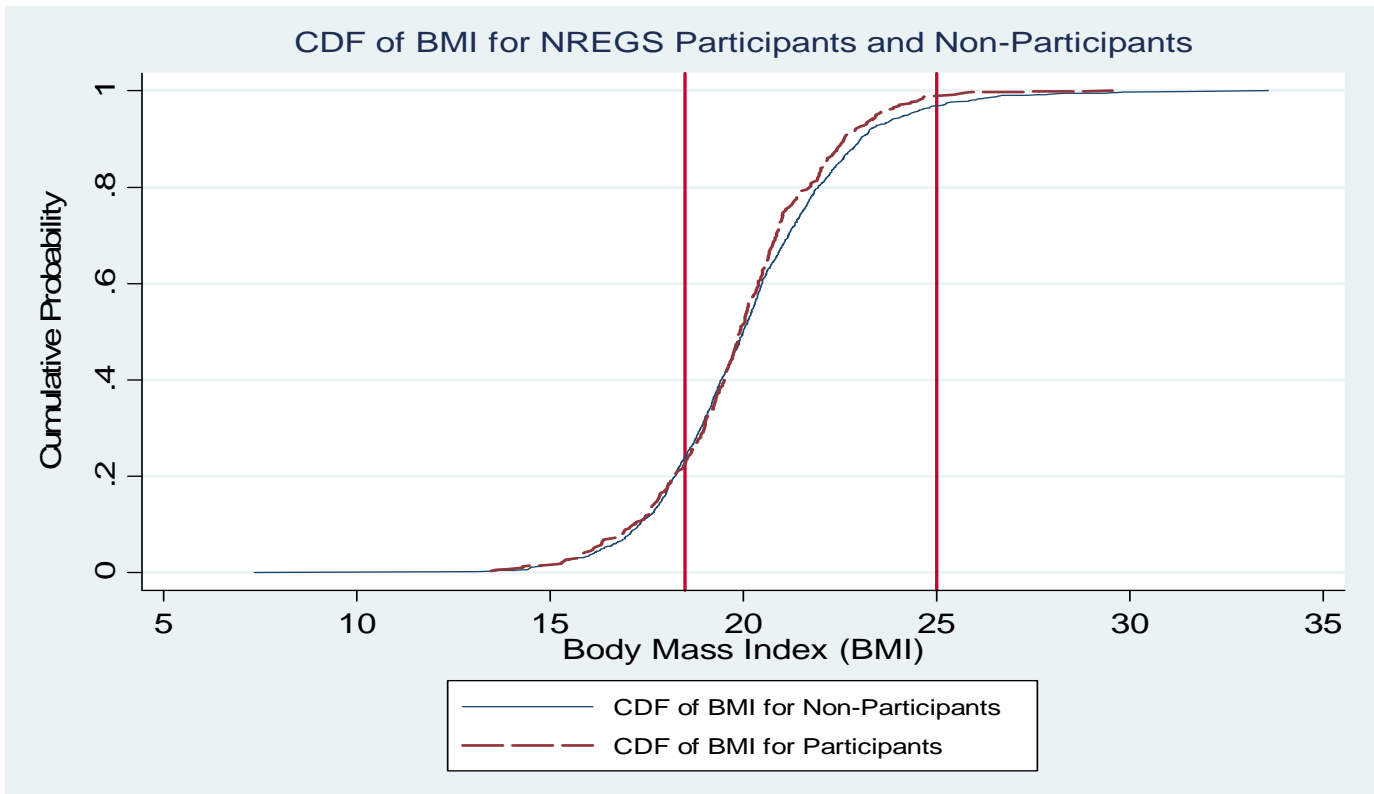

Note: vertical reference lines are drawn at 18.50 and 24.99 , respectively

Figure 2: Cumulative Distribution Functions of Body Mass Index $\left(\mathrm{kg} / \mathrm{m}^{2}\right)$ for Poor and Non-poor NREGS Participants in Rajasthan: 2009-10

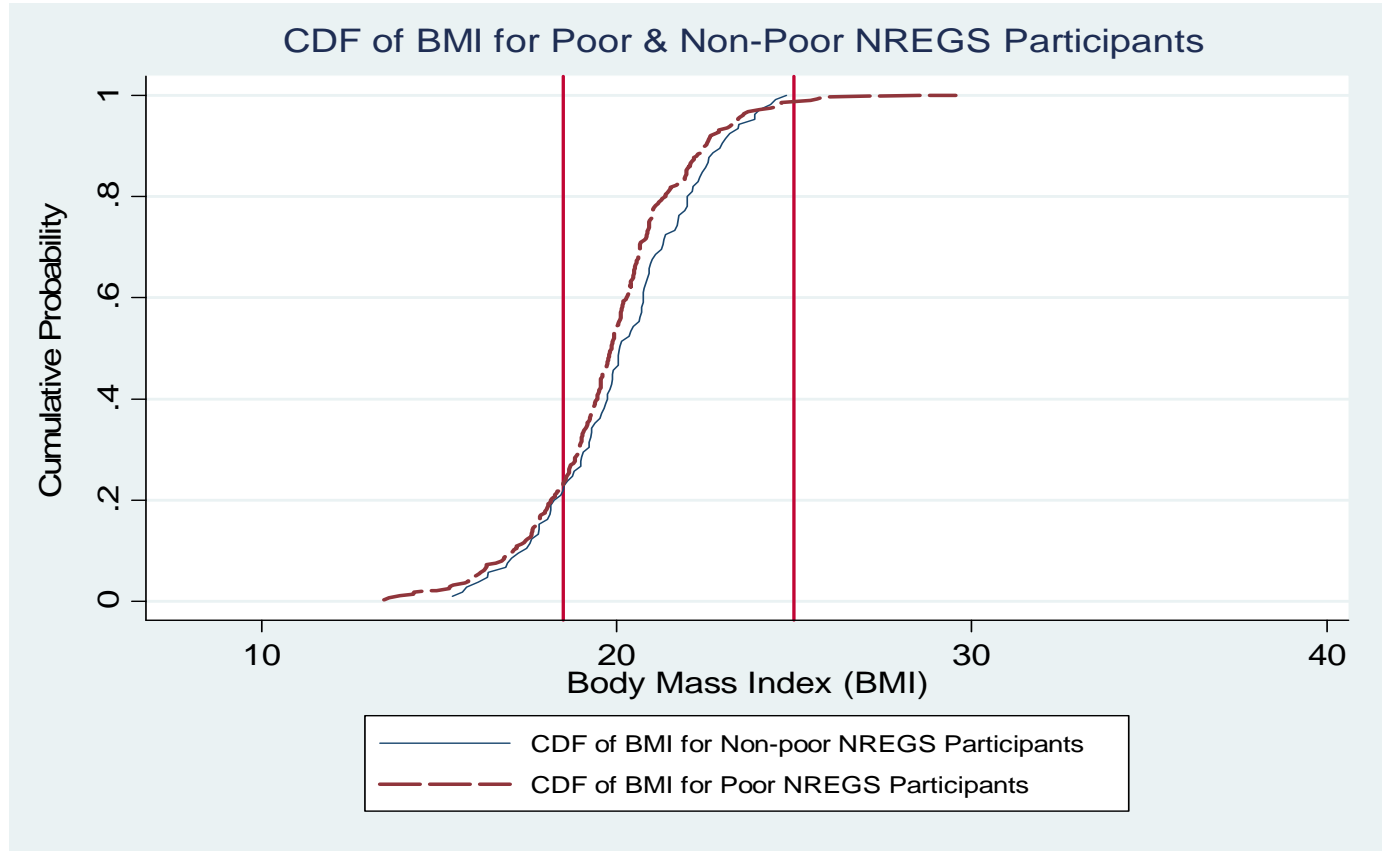

Note: vertical reference lines are drawn at 18.50 and 24.99 , respectively 
Figure 3: Cumulative Distribution Functions of Number of Days Worked by NREGS Participants for Underweight, Normal and Overweight NREGS Participants in Rajasthan: 2009-10

CDF of Days Worked in NREGS by BMI Categories of NREGS Participants

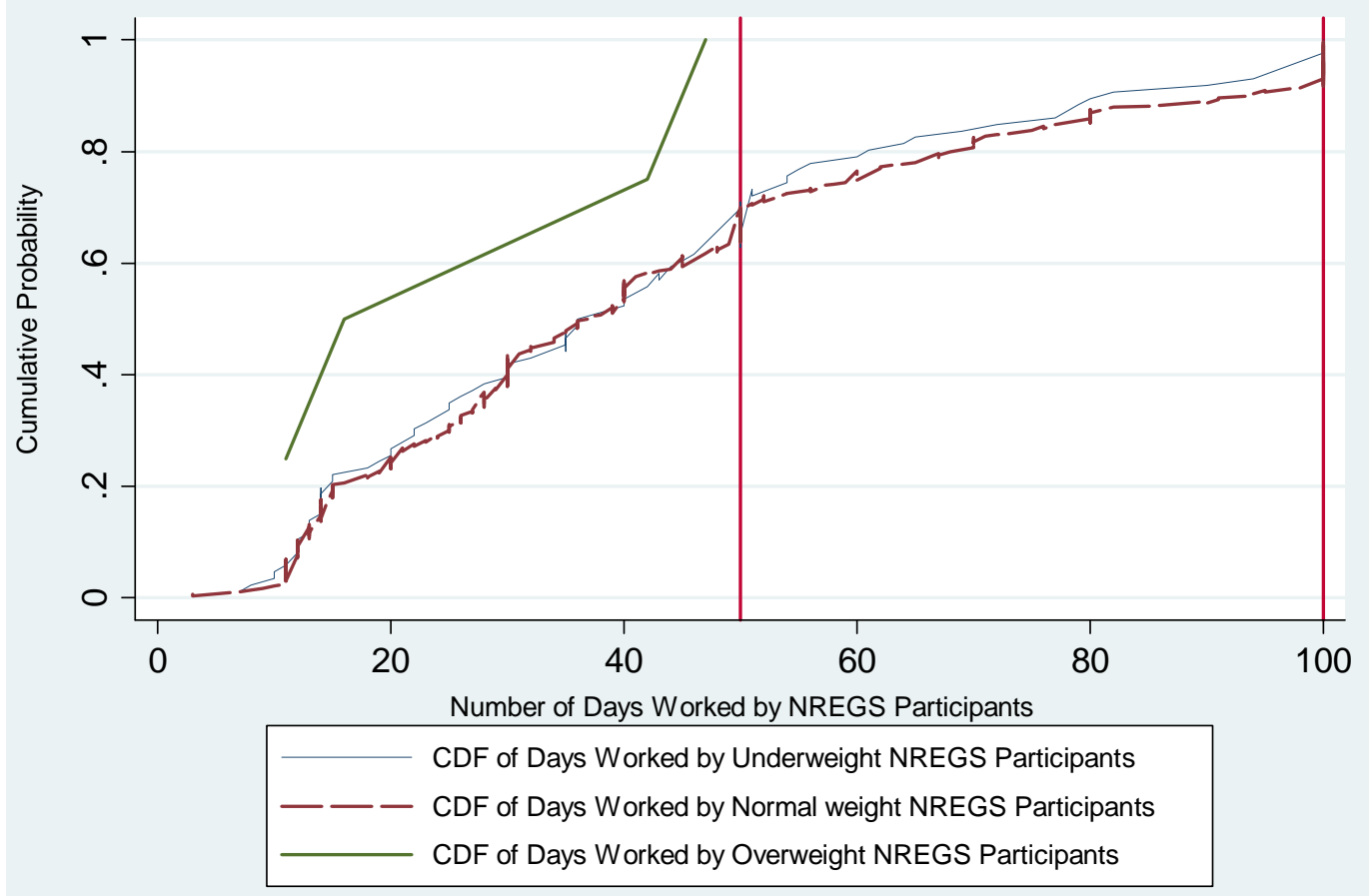

Note: vertical reference lines are drawn at 50 and 100, respectively

Figure 4: Cumulative Distribution Functions of NREGS Wage Earnings (in INR) for Underweight, Normal and Overweight NREGS Participants in Rajasthan: 2009-10

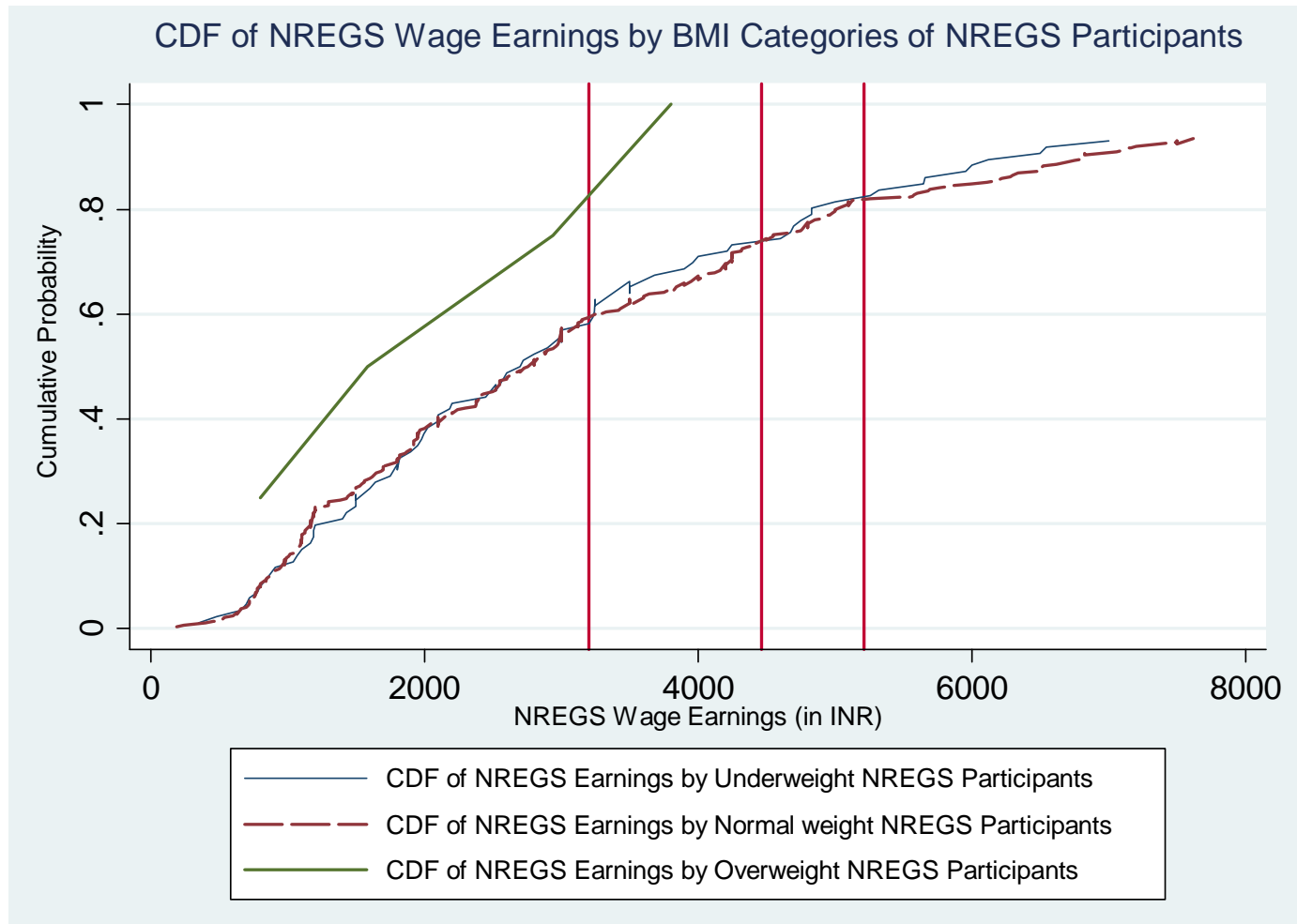

Note: vertical reference lines are drawn at 3203.68, 4465.68 and 5210.48, respectively 
Table A.1

The International Classification of adult underweight, normal and overweight according to BMI

\begin{tabular}{|l|l|}
\hline BMI Classification & \multicolumn{1}{|c|}{ Cut-off points for body mass index: BMI $\left(\mathrm{kg} / \mathrm{m}^{2}\right)$} \\
\hline Underweight & $<18.50$ \\
\hline Normal & $\geq 18.50$ and $\leq 24.99$ \\
\hline Overweight & $\geq 25.00$ \\
\hline
\end{tabular}

Source: Adopted from World Health Organisation (WHO) website

Table A.2

Disaggregation of Households by Poverty Status

\begin{tabular}{|l|l|}
\hline Levels of poverty & Per capita monthly consumption expenditure (PCME) in INR \\
\hline Acute poverty & $<480$ \\
\hline Moderate poverty & $\geq 480$ but $<565$ \\
\hline Moderate Non-poverty & $\geq 565$ but $<735$ \\
\hline Affluent & $\geq 735$ \\
\hline Poor & $<565$ \\
\hline Non-poor & $\geq 565$ \\
\hline
\end{tabular}


Table A.3

Definition of the variables used in the analysis

\begin{tabular}{|c|c|}
\hline Variables & Definition \\
\hline \multicolumn{2}{|l|}{ Dependent Variables } \\
\hline BMI & Body mass index (=weight in kg/square of heights in meter) \\
\hline BMI Categories & Ordered: 1=Underweight, 2=Normal, 3=Overweight \\
\hline NREGS Participation & $=1$ if participated in NREGS; 0 otherwise \\
\hline Duration of work in NREGS & Log of number of days worked in NREGS during last year \\
\hline NREGS Earnings & Log of annual wage earnings from NREGS participation \\
\hline \multicolumn{2}{|l|}{ Explanatory Variables } \\
\hline Gender & $=1$ if male, 0 if female \\
\hline Age & Age of household member \\
\hline Square of age & Square of age \\
\hline Illiterate & Omitted group \\
\hline Primary education & $=1$ if literate but upto primary education, 0 otherwise \\
\hline Middle school & $=1$ if literate but upto middle school, 0 otherwise \\
\hline Secondary education & $=1$ if literate but upto secondary education, 0 otherwise \\
\hline Higher secondary and above & $=1$ if literate but upto higher secondary and above, 0 otherwise \\
\hline SC & $=1$ if social group is SC, 0 otherwise \\
\hline ST & $=1$ if social group is ST, 0 otherwise \\
\hline $\mathrm{OBC}$ and & $=1$ if social group is $\mathrm{OBC}, 0$ otherwise \\
\hline Others & Omitted group \\
\hline Land owned & Amount of land owned (in acre) \\
\hline Household size & Size of the household \\
\hline Square of household size & Square of size of the household \\
\hline Ratio of NREG to AGR wage rate & Ratio of NREG wage to agricultural wage rate at the village level \\
\hline Land Gini index & $\begin{array}{l}\text { Land Gini index to measure inequality in the distribution of landholdings } \\
\text { at the village level }\end{array}$ \\
\hline Land per household in the village & $=$ Total land in the village divided by number of households in the village \\
\hline $\begin{array}{l}\text { Interaction of land per household and } \\
\text { land Gini index at the village level }\end{array}$ & Interaction of land per household and land Gini index at the village level \\
\hline $\begin{array}{l}\text { Interaction of Ratio of NREG to AGR wage rate } \\
\text { and Land Gini index }\end{array}$ & Interaction of Ratio of NREG to AGR wage rate and Land Gini index \\
\hline BMI (IV) & Predicted BMI from robust regression equation \\
\hline Normal (IV) & Predicted probability of being normal from ordered probit regression equation \\
\hline Overweight (IV) & Predicted probability of being overweight from ordered probit regression equation \\
\hline Underweight (IV) & Omitted \\
\hline Predicted Probability of Participation at village level(I) & $\begin{array}{l}\text { Predicted Probability of Participation from Specification } 1 \text { of Table } 6 \text { and } \\
\text { aggregated at village level }\end{array}$ \\
\hline Predicted Probability of Participation at village level(II) & $\begin{array}{l}\text { Predicted Probability of Participation from Specification } 2 \text { of Table } 6 \text { and } \\
\text { aggregated at village level }\end{array}$ \\
\hline
\end{tabular}

